\title{
Confidence and caretakers: Some less-obvious implications of the Fixed-term Parliaments Act
}

\author{
Author details \\ Dr James Strong is Lecturer in British Politics at Queen Mary, University of London.
}

\begin{abstract}
This article explores the Fixed-term Parliaments Act's less-obvious implications. First, it discusses why Theresa May found calling the 2017 election so straightforward, and notes what this implies for how FTPA works. Second, it looks at executive-legislative relations. FTPA removed the government's ability to designate controversial parliamentary votes matters of confidence, and introduced a fourteen-day cushion between a no-confidence vote and parliament's dissolution. In the process it shifted the balance of power from ministers to backbenchers, to an extent potentially greater than most observers recognise. Third, it considers the more outlandish possibilities raised by FTPA's imposition of a fourteen-day waiting period after a government's defeat on a no-confidence motion before a new election can be called. It is possible, for example, for rebel MPs from the governing party to use the no-confidence procedure to force concessions from the cabinet. Finally, it assesses FTPA's long-term survival prospects, and what repeal would involve.
\end{abstract}

\section{Keywords}

British politics, constitution, House of Commons, fixed-term parliaments, executive-legislative bargaining, parliamentary dissolution. 
When the Fixed-term Parliaments Act (FTPA) passed in the summer of 20I I, it fundamentally altered - at least in theory - how British governments form, function, and fall. FTPA imposed new statutory limitations on the Prime Minister's historic power, under the Royal Prerogative, to dissolve parliament and call a general election at a politically opportune moment of their choosing. Elections should now normally take place every five years, unless one of two scenarios occurs: either two-thirds of all MPs agree to permit the government to call an early election, or the government loses a no-confidence vote and no viable alternative government emerges within fourteen days.

This article explores FTPA's outer limits and less-obvious implications. First, it discusses why Theresa May found calling the 2017 election so straightforward, and notes what this implies for how FTPA works. Second, it looks at executive-legislative relations. FTPA removed the government's ability to designate controversial parliamentary votes matters of confidence, and introduced a fourteen-day cushion between a no-confidence vote and parliament's dissolution. In the process it shifted the balance of power from ministers to back-benchers, to an extent potentially greater than most observers recognise. Third, it considers the more outlandish possibilities raised by FTPA's imposition of a fourteen-day waiting period after a government's defeat on a no-confidence motion before a new election can be called. It is possible, for example, for rebel MPs from the governing party to use the no-confidence procedure to force concessions from the cabinet. Finally, it assesses FTPA's long-term survival prospects, and what repeal would involve. 


\section{Theresa May's election}

FTPA emerged from the coalition agreement between the Conservative and Liberal Democrat Parties after the 2010 election. Its stated purpose was to fix the gap between elections at five years. In that, it failed. On I8 April 2017, less than two years on from the previous election, Theresa May announced that she planned to go to the country. It was a bold statement, given she still needed to secure super-majority support in parliament. But it worked. The next day $522 \mathrm{MPs}$ - well over the two-thirds threshold set by FTPA - approved an early election.

Under FTPA, a government possessing a parliamentary majority and determined to force an early election could conceivably engineer a so-called 'constructive' no-confidence vote in itself. It might face a legal challenge - by stipulating in statute what constitutes a no-confidence motion, FTPA makes the issue justiciable - but even if a court agreed to hear the case, the government would likely prevail. German Chancellors Kohl and Schröder both won Federal Constitutional Court judgements after using constructive no-confidence votes to trigger early elections in 1982 and 2005, and there is no explicit restriction on the practice in FTPA. Given the risks of calling an early election, so brutally illustrated in 2017 - and, indeed, by Schröder's defeat in 2005 - a future government might not want to appear weak by losing a noconfidence vote, even on its own initiative'. But the option would be there.

Things look still more complicated if the government lacks a majority. FTPA makes it harder for minority governments to collapse. That may prolong their existence, but it does not necessarily make them more effective ${ }^{2}$. A minority government might find itself unable to pass legislation but prevented from calling a fresh election, even through the no-confidence route. 
The question obviously arises of whether a credible opposition would vote against a motion expressing no confidence in the government, but it clearly could.

Assuming the government retains a majority and does not want to pass a no-confidence motion in itself, the two-thirds threshold should ensure that no British prime minister can call an election simply to take advantage of favourable polls. Even Tony Blair's landslide victory in 1997 left him with less than two thirds of all MPs at his disposal. Most observers expected the super-majority route would only work in a national emergency or a case of total political gridlock. They asked why a government would want an election unless it expected to increase its majority, and why the opposition would agree if it expected to lose ${ }^{3}$. Sure enough, Theresa May acted in April 2017 because opinion polls predicted a Conservative landslide. Labour could have vetoed the whole thing. But, confounding observers' earlier expectations, it demurred.

Three plausible explanations exist for what looked, at the time, like an act of political suicide. First, while FTPA grants MPs the legal right to veto an early election, that power has never been used. Labour may not have grasped how significant a change FTPA involved. It could have rejected May's request. It need not even have voted no - simply abstaining would have been enough, since calling an early election under FTPA with the present 650-seat configuration of the House of Commons requires 434 positive votes. Yet this did not necessarily seem obvious to the Labour leadership. FTPA is new. It has to compete for space in MPs' imaginations with hundreds of years of accumulated precedents, all of which suggest the government should have the right to call an election when it chooses. Perhaps the first thing we learn from the 2017 election is that long-established conventions retain a powerful pull over the minds of politicians. 
Second, forced to decide between two unattractive poultry-related metaphors, Labour likely preferred resembling turkeys (voting for Christmas) over chickens. As early as 20I2, Patrick Dunleavy argued that FTPA lacked real substance, since no serious opposition leader can afford to appear afraid of voters ${ }^{4}$. His prediction - of a June 2014 election - failed because the Conservative Party's opinion poll position never improved, meaning David Cameron was never confident he could win. Refusing to support an early election would have meant admitting that Labour expected to lose, and losers do not gain votes. Political calculations influence Britain's unwritten constitutional rules, and on this occasion Labour's calculation that opposing elections looks bad seems to have rendered its right to do so moot.

Finally, of course, it is possible that Labour accurately anticipated its better-than-expected performance in the resulting election. As the campaign laid cruelly bare, Jeremy Corbyn is a more capable vote-winner than Theresa May. In the Labour Party's much-expanded membership, and in the pro-Corbyn social movement Momentum, he possesses considerable and as yet under-studied advantages. It is possible he correctly predicted that he could beat the pollsters' predictions. He may have understood that merely avoiding annihilation from such an apparently low base would secure his leadership; it is difficult to under-perform when expectations are so low. It is also possible that Labour recognised what academic research shows: voters punish governments that call unnecessary elections ${ }^{5}$. Straight after May's announcement, a BBC video clip went viral when a voter identified as 'Brenda from Bristol', on hearing there would be an election soon, responded half in anger and half in shock; 'you're joking. Not another one?!' . Brenda, it seems, may not have been alone in her exasperation.

Early elections, we learned in 2017, can indeed happen under FTPA. Governments can propose a vote and dare the opposition to refuse. It is unclear what combination of 
convention, confidence and fear of looking chicken caused Labour to accede to Theresa May's request. It is clear that it could have refused. What will happen the next time a government demands an early election is consequently unknowable. We cannot tell whether a future government will take the risk May took, given what it cost her, nor how a future opposition will respond. We can say only what the options are, once the government decides it is time for an election: agree, and risk defeat; refuse, and look cowardly; abstain, and cause confusion.

\section{Intra-party bargaining}

Not only did FTPA fail in practice to abolish the government's power to call early elections, it also produced unintended results. This was in many ways unsurprising. Both MPs and Lords criticised the haste with which the government advanced the Fixed-term Parliaments Bill, without serious pre-legislative consultation or scrutiny. Several issues arose during the legislative process, forcing the government to accept significant revisions. The most significant drafting changes affected no-confidence votes. FTPA introduced two innovations in this area. First, it stipulated the precise wording a motion of no confidence in the government must take to trigger an early election. Second, it introduced a fourteen-day delay between the government's defeat on a no-confidence vote and the Prime Minister gaining the right to request parliament's dissolution.

Both innovations were necessary. Without the fourteen day time limit, a government could be left in power after defeat on a no-confidence vote for the remainder of the five year parliamentary term, able to act only under caretaker conventions. Without clearly stipulating what constituted a no-confidence vote, FTPA potentially opened the question to interpretation by the courts. Ministers originally proposed that the definition of confidence 
should continue to be based solely on precedent. But it proved impossible to restrict when parliament could dissolve in some circumstances without covering every possible scenario. The very act of legislating made the matter potentially justiciable. This caused consternation. The Clerk of the House of Commons even asked the government to shelve the entire Bill, and to rely on the Standing Orders of the House - which are exempt from judicial scrutiny to achieve its goals. In the end the government accepted an amendment at the Report Stage in the House of Lords that made the question difficult to dispute. A no-confidence motion that does not take the form stipulated in FTPA 201 I s2(4) might force the government to resign, but it cannot trigger an early election.

Before FTPA three forms of no-confidence vote existed. First, MPs could approve an explicit motion stating they lacked confidence in the government, like the one that brought down James Callaghan's Labour government in 1979 and launched Margaret Thatcher's premiership. Second, MPs could implicitly express their lack of confidence in the government by voting down the Budget or the Queen's Speech, as they did to Stanley Baldwin in 1924. Finally, the government could designate a contentious parliamentary vote as a question of confidence in itself.

By specifying the form of words no-confidence motions must take to begin the process of triggering an early election, FTPA alters the conventions it replaced. Implicit and designated confidence motions remain possible, but they no longer carry the same force. Before FTPA, a government defeated on an implicit or designated confidence motion faced a choice: it could resign and recommend a successor, or call an election. Under FTPA, the option of calling an election only arises once fourteen days have elapsed with no government winning a positive confidence vote. Fourteen days can be a long time in British politics. 
While this shift has implications for implicit confidence votes, it matters most for the designated sort. Prime Ministers have historically used the threat of a no-confidence vote to force rebellious back-benchers to choose between backing down and facing the electorate. As Lord Norton has noted, when FTPA broke the link between a designated confidence motion and the threat of a fresh election, it essentially abolished this power ${ }^{7}$. That weakened the executive's power vis-à-vis the legislature.

Both international and domestic comparisons suggest that the mere possibility of a designated confidence vote, even if none is explicitly threatened, bolsters a government's parliamentary support. Historical experience suggests even implicit threats work, while comparison to recent examples underlines what governments have lost. Tony Blair shored up Labour support for war in Iraq in 2003 by suggesting a link between the final House of Commons vote and confidence in his government. David Cameron lacked the capacity to do the same over Syria in 2013, and lost ${ }^{8}$. Both Ted Heath (over accession in 1972) and John Major (over Maastricht in 1993) used designated confidence motions to corral Eurosceptic Conservative MPs into supporting Europe-related legislation. Facing the even greater challenge of navigating Brexit without a majority, Theresa May was unable to follow suit. Though she could still threaten to resign if her back-benchers deserted her, that threat carried much less weight. It no longer meant they themselves might lose their jobs.

FTPA arguably makes more of a difference than has hitherto been observed. Others have shown how FTPA denuded Downing Street of the power to discipline government MPs with the threat of an early election, potentially giving greater licence to rebels. But few recognise that MPs have also gained something. A no-confidence vote in the government no longer automatically triggers a general election. That makes no-confidence votes intrinsically less of 
a threat to rank-and-file MPs. Governments can resign if defeated on issues they consider matters of confidence. A no-confidence vote only leads to an election if it follows the formula prescribed by FTPA and MPs do not within fourteen days pass a fresh motion either restoring confidence to the existing government or conferring it upon a new government. The power to decide whether a no-confidence vote leads to a fresh election has not disappeared. It has instead been transferred to a majority of MPs.

Designated confidence motions gave governments the power to trigger a game of chicken with parliamentary rebels, threatening an election to compel compliance. By interposing a fourteen day waiting period between a no-confidence vote and the point at which the Prime Minister can call a fresh election, FTPA gives that same power to back-benchers. Rebel government MPs - or junior coalition partners - can defect on a no-confidence vote, demand concessions, then reverse course before the fourteen day clock times out. Not only was Theresa May's Brexit strategy hamstrung by her inability to use designated confidence motions to discipline rebels - of whichever persuasion - she also faced the constant possibility that a small group of MPs - whether hardline Brexiters, recalcitrant Remainers, the Scottish Conservative contingent or the DUP - could vote with the opposition to start the clock running towards a fresh election, knowing they alone had the power to turn back depending on who blinked first.

Rebel MPs might use this threat in different ways. As with designated confidence motions, it seems unlikely that they would regularly, if ever, actually use a no-confidence vote to coerce the government. The stakes would be too high. But the mere possibility should influence government calculations. Rebels could use the shadow of a confidence vote to extract a policy shift, to win targeted public spending - as the DUP effectively did in reaching its confidence- 
and-supply arrangement with May after the 2017 election - or to demand a change in leadership, essentially reversing the way governments used it before FTPA.

Among these possibilities, one stands out. In theory, government MPs could defy the whip, vote with the opposition on a no-confidence vote, then present the Prime Minister with an ultimatum: step down and accept a replacement candidate, or face electoral defeat. Conservative MPs seem unlikely to pursue this course. Just $15 \%$ of them can trigger a leadership ballot according to the Party's rules. If an alternative candidate truly possessed broad support, it would be less risky for MPs to use internal mechanisms rather than threatening an election to get their way. Even so, meeting the $15 \%$ threshold during the 2017 parliament required 48 MPs to turn against May. She could be defeated on a no-confidence motion by just four MPs switching sides. Arguably, FTPA allows smaller groups of rebels greater leverage over Number 10.

Things look even more interesting when we consider the prospect of a future Labour government led by Jeremy Corbyn. Even allowing for Corbyn's influence over the selection of new MPs, and the aura of victory that would necessarily surround his entry to Downing Street, it seems likely he would still enjoy only grudging support from many members of the Parliamentary Labour Party. That support could evaporate upon contact with governing reality. Unlike their Conservative counterparts, Labour MPs lack a decisive internal mechanism to remove their leader should they disapprove of his policies in office. Assuming Corbyn does not resign, the best Labour MPs can do is to trigger a fresh leadership election. They learned in 2016 what that entailed. Corbyn would stand again, and probably win. 
Under the terms of FTPA, however, Labour back-benchers would have a new nuclear option in their interactions with a Corbyn-led government. They could use a no-confidence motion to give the leadership an ultimatum: stand aside and let the PLP choose a successor, or face the voters. Corbyn might prefer to take his chances in an election, especially after the experience of 2017 , and that might in turn lead rebels to think again. But the possibility of forcing the issue would be there. It would be easier for Labour rebels to eject Jeremy Corbyn from Downing Street than it is for them to remove him from the Party leader's office.

Rebellious Conservative MPs tried to reformulate the no-confidence procedure during the 1990s so they could target the Prime Minister without risking an election. They failed. By introducing a fourteen day waiting period after a no-confidence vote, FTPA has in effect reintroduced this possibility. It has shifted the balance of power from the executive to the legislature, granting back-bench MPs new leverage over the government. Whether they will in fact use the nuclear option remains to be seen. That they could do so, while retaining the power to reverse course should the government refuse to back down, looks clear.

\section{A lot can happen in fourteen days}

We have already seen that the fourteen day waiting period gives rebellious back-benchers room to negotiate hard with their erstwhile leaders. It also makes possible - albeit unlikely a string of more peculiar scenarios.

Firstly, FTPA makes it possible for a Prime Minister to gain office temporarily despite never having won an election and being unable to command a majority in the House of Commons. Under section 2(3), the fourteen day period that begins with a no-confidence vote can end in 
one of two ways. Either the clock times out, and there must be a general election, or the House passes a motion stating 'that this House has confidence in Her Majesty's Government'.

This is significant. FTPA could have required MPs to invest the government, abolishing the Royal Prerogative to appoint the Prime Minister and giving that right to the House of Commons. Similar investiture votes take place elsewhere. One cannot become German Chancellor without winning a vote in the Bundestag, or Scottish First Minister without winning a vote at Holyrood. No such procedure exists at Westminster. In fact, the wording of FTPA makes clear that one must be appointed Prime Minister before a positive confidence vote can be called. The question is not hypothetical; MPs do not choose who forms the government. Their power extends only to supporting Her Majesty's Government. Her Majesty has to make the appointment first.

Whips miscount. Senior politicians might sincerely believe that they have cobbled together a deal in the frantic period after a government loses a no-confidence vote - involving a change of policy, of leadership, of coalition structure or of governing party. They might be wrong. It would only become clear when the newly-appointed Prime Minister failed to get a positive confidence motion approved. Leading politicians would then have a choice. The largest parties could agree to call an election immediately using the two-thirds vote route, ending the uncertainty. They could even do a deal to grant the Prime Minister confidence, to temporarily legitimise their position, in return for an immediate election thereafter. They could also, either by design or disagreement, let the fourteen day clock run out. Under this final scenario, the new Prime Minister would remain in office, unelected and without parliamentary support, under the caretaker conventions described in the Cabinet Manual. Their main power would 
be to set the date of the fresh election, and so formally to request parliament's dissolution. They would remain in office until after the election result.

Much would depend, at that point, on convention. The Cabinet Manual has no legal status. Nor do the caretaker conventions it describes. The Cabinet Secretary might argue it would be improper for the government to act outside of the bounds set down in the text, but they would have no legal authority to refuse ministerial instructions. In the event of a crisis, perhaps related to the situation in parliament, or perhaps unrelated to it, an unelected Prime Minister without the confidence of the House of Commons could nevertheless use the Royal Prerogative to deploy the armed forces or delay an election for the remainder of the existing parliament's five-year duration. Though the explanatory notes to FTPA make clear that the Prime Minister is expected to use their power to delay an election (once the fourteen day clock runs out) only to complete essential business or to ensure that polling day falls on a Thursday, the actual text of the legislation imposes no such limitation, and there is no clear definition anywhere of what constitutes 'essential business'. Francis Urquhart would undoubtedly approve.

Secondly, a Prime Minister defeated on a no-confidence motion might refuse to resign, arguing that they cannot recommend a successor. They could do so even if an alternative candidate was in fact capable of winning a confidence vote. Again, the procedure for a positive confidence vote set out by FTPA assumes the new government has already been appointed by the Queen. Such an appointment cannot take place until the previous Prime Minister has either resigned or been dismissed. According to the Cabinet Manual, the 'Prime Minister is expected to resign where it is clear that he or she does not have the confidence of the House and that an alternative government does have the confidence', which suggests there would be 
scope for the Cabinet Secretary to apply pressure to a recalcitrant PM ${ }^{9}$. But they would have no legal power to force the issue.

Relatedly, a defeated Prime Minister could ask the Queen to prorogue parliament, making it impossible for a rival to win a positive confidence vote during the fourteen day waiting period. The Cameron government believed that such 'political gamesmanship... would result only in a damning verdict from the electorate' and warned that the 'political safeguards in our constitution should not be underestimated ${ }^{10}$. It is in fact unclear whether other governments have suffered penalties for attempting similar shenanigans. Canadian Prime Minister Stephen Harper, for example, got away with using prorogation to avoid a no-confidence vote in 2008. The then Minister for Constitutional Reform told MPs during debate on FTPA that it would be for the Queen to step in at that point. Whether she actually would step in remains to be seen - since doing so would inevitably embroil her in party politics. But she, and she alone, would have the authority to intervene, something both the Cabinet Secretary and the Palace have repeatedly made clear they desperately want to avoid.

Thirdly, the Prime Minister might be willing to resign but find the leader of the opposition unwilling to form a government. Lord Norton speculated that this scenario could leave Britain without a government, potentially for up to five years" ${ }^{\prime \prime}$ That remains theoretically possible, but highly implausible. The Cabinet Manual notes that 'the government retains its responsibility to govern' until it is clear that it can be replaced ${ }^{12}$. The Manual does not indeed, it cannot, since there is no statutory basis for such a statement - say that the government must wait on its successor before submitting its resignation. This contrasts with the position in most international comparator states, which do not allow caretaker governments to resign ${ }^{13}$. But it is clear that the Queen can refuse to accept a government's 
resignation if she is not satisfied that a viable alternative exists - as Queen Victoria initially did when Lord Aberdeen attempted to step aside in favour of Viscount Palmerston in 1855. There is a meaningful distinction between the government's tendering its resignation to the monarch, and the monarch's acceptance. Before FTPA the monarch retained the right to refuse to dissolve parliament under certain circumstances, for example if scope remained for a viable alternative to be formed. George V, for example, stayed Ramsay MacDonald's request to dissolve parliament in 1924 to confirm that neither the Liberal nor Conservative leaders stood ready to replace him as Prime Minister. FTPA makes that scenario impossible, but says nothing about the monarch's right to refuse the government's resignation. If the Prime Minister offers to resign without being able to recommend a successor, the Queen has the right - and, arguably, the duty - to refuse.

It would in practice fall to the Queen's Private Secretary and the Cabinet Secretary jointly to ensure that no outgoing Prime Minister is received at Buckingham Palace until they can credibly recommend a successor. Britain should only be left without a government if these two officials get their calculations wrong - if it becomes clear only in the minutes after the Prime Minister has resigned that no-one is in fact willing to take over. That seems implausible. It would require a spectacular breakdown in lines of communication, or outright dishonesty on somebody's part.

FTPA thus makes thinkable some peculiar scenarios that were unthinkable before it passed. Britain could wind up with an unelected Prime Minister who lacks the confidence of the House of Commons. The Queen could be forced to dismiss a Prime Minister who refused to give way to a credible successor. She could, just about, be left without a government, or forced to keep a Prime Minister in office who wished to step aside. Much would depend on 
convention, on the Cabinet Manual, and on the behind-the-scenes maneuvering of two unelected officials - the Cabinet Secretary and the Queen's Private Secretary.

\section{Conclusion: FTPA's future}

Critics of FTPA frequently call for its repeal. As we have seen, FTPA does not in practice prevent governments calling opportunistic elections. Instead, it reduces their ability to discipline rebellious back-benchers, and potentially makes some strange scenarios possible. It has served its true political purpose, in that the Conservative-Liberal Democrat coalition ran its full five year course. Yet repeal may not be straightforward.

Constitutional experts disagree over whether simply abolishing FTPA would restore the status quo ante. Andrew Blick, for example, argued that repealing FTPA would allow the Royal Prerogative to dissolve parliament to spring back into life, restoring the Prime Minister's previous power ${ }^{14}$. In fact, the explanatory notes to FTPA make clear that much of the debate stems from a confusion reproduced in Blick's argument. FTPA does not abolish the Prerogative of dissolution, it merely constrains it. Explanatory note 30 clarifies that, under s2(7) FTPA 201 I, 'dissolution does not follow automatically on a triggering event', namely a two-thirds super-majority vote or an unmitigated no-confidence vote, and that in fact 'the Queen sets the date for an early election by proclamation on the recommendation of the Prime Minister ${ }^{\prime 15}$. Repealing FTPA would, in other words, largely restore the situation that existed before 20II, lifting the constraints imposed on the dissolution prerogative without affecting the underlying power. As Lord Norton rightly notes, the repeal legislation would need to reinstate the stipulations previously contained in the Septennial Act of 1715 and s7 
Parliament Act 1911, which together limited the period between elections to five years and which were both themselves repealed by FTPA ${ }^{16}$. That hurdle is surely surmountable.

Whether FTPA will in fact be repealed depends ultimately on politics. It depends on whether the main party leaders conclude the restrictions it imposes do them more harm than good. It depends on whether the government can secure a majority for repeal without the power of a designated confidence vote, a far-from-trivial consideration in a period of hung parliaments. It also depends on whether any of the strange scenarios set out in this article actually come to pass. Each involves, to some degree, the violation of constitutional conventions. While politicians can behave unconventionally without facing legal censure, one of the most significant facets of the UK constitution is that they generally do not. None of the more outlandish occurrences described above is likely. Yet all are possible, and that may be enough to prompt action. 


\section{References}

' A. Blick, 'Constitutional implications of the Fixed-Term Parliaments Act 20I I', Parliamentary Affairs, vol. 69, no. I, 2016, p. 28.

${ }^{2}$ S. Swan, 'An invitation to adventurism: The Fixed-term Parliaments Act can and will crucify a minority government', Democratic Audit UK, 30 April 2015, http://www.democraticaudit.com/2015/04/30/an-invitation-to-adventurism-the-fixedterm-parliament-act-can-and-will-crucify-a-minority-government/, retrieved 9 November 2017.

${ }^{3}$ P. Schleiter and S. Issar, 'Constitutional Rules and Patterns of Government Termination: The Case of the UK Fixed-Term Parliaments Act', Government and Opposition, vol. 5I, no. 4, 2016, p. 623.

${ }^{4}$ P. Dunleavy, 'Fixed term parliaments are a mirage - it's all downhill from now to a June 2014 general election', British Politics and Policy @ LSE, 20 February 2012, http://blogs.Ise.ac.uk/politicsandpolicy/20 I2/02/20/general-election-20 I4-dunleavy/2 retrieved 9 November 2017.

${ }^{5}$ R. Hazell, 'Is the Fixed-term Parliaments Act a dead letter?', The Constitution Unit, UCL, 25 April 2017, https://constitution-unit.com/2017/04/25/is-the-fixed-term-parliamentsact-a-dead-letter/, retrieved 10 November 2017.

${ }^{6}$ BBC News Online, 'Views from Bristol after snap election announcement', 18 April 2017, http://www.bbc.co.uk/news/av/uk-politics-39631693/views-from-bristol-after-snapelection-announcement, retrieved 10 November 2017.

${ }^{7}$ P. Norton, 'The Fixed-term Parliaments Act and Votes of Confidence', Parliamentary Affairs, vol. 69 , no. I, 2015 , p. 15. 
${ }^{8} \mathrm{~J}$. Strong, 'Interpreting the Syria vote: Parliament and British foreign policy', International Affairs, vol. 9I, no. 5, 2015, p. II36.

${ }^{9}$ HM Government, The Cabinet Manual, London, TSOL, 20II, p. I5. Emphasis added.

${ }^{10} \mathrm{HM}$ Government, Government response to the report of the Political and Constitutional Reform Committee on the Fixed-term Parliaments Bill, CM 795I, London, TSOL, 20I0, p. 9.

I P. Norton, 'From flexible to semi-fixed: The Fixed-Term Parliaments Act', Journal of International and Comparative Law, vol. I, 2014, p. 220.

${ }^{12}$ HM Government, The Cabinet Manual, London, TSOL, 20I I, p. 17.

${ }^{13} \mathrm{P}$. Schleiter and V. Belu, 'The challenge of periods of caretaker government in the UK', Parliamentary Affairs, vol. 68, no. 2, 2015, p. 229.

${ }^{14}$ A. Blick, 'Constitutional implications of the Fixed-Term Parliaments Act 20 I I', Parliamentary Affairs, vol. 69, no. I, 2016, p. 30.

${ }^{15}$ Fixed-term Parliaments Act 201 I, Explanatory Note 30.

${ }^{16}$ P. Norton, 'Repealing the Fixed-term Parliaments Act?', The Norton View, 8 October 20I6, https://nortonview.wordpress.com/2016/10/08/repealing-the-fixed-term-parliamentsact/, retrieved 25 November 2017. 